\title{
APO Regimen
}

National Cancer Institute

\section{Source}

National Cancer Institute. APO Regimen. NCI Thesaurus. Code C67210.

A regimen consisting of doxorubicin, prednisone and vincristine, used for the treatment of disseminated, childhood, anaplastic large-cell lymphoma (ALCL). 